\title{
Ecological Energetics of the Golden Mouse Based on Three Laboratory Diets
}

Karen L. STUECK, Michael P. FARRELL \& Gary W. BARRETT

Stueck K. L., Farrell M. P. \& Barrett G. W., 1977: Ecological energetics of the golden mouse based on three laboratory diets. Acta theriol., 22, 22: 309-315 [With 2 Tables \& 1 Fig.].

Various energetic parameters of the golden mouse, Ochrotomys nuttalli, were measured for three different laboratory diets. No significant group weight changes due to the effect of diet were found. While food intake (g/g wet $\mathrm{wt}$ ) was found to be significantly different $(P \leq 0.05)$ between the highest and lowest caloric diets, no differences were found between ingestion rates based on caloric content. Fecal production for all diets differed significantly $(P \leq 0.05)$. Accordingly, mean assimilation efficiencies on all diets were found to be significantly different $(P \leq 0.05)$. These findings indicate that the caloric needs of this species are met by varying the rate of food intake as a function of dietary (caloric) composition.

[Dept. Zool., Miami Univ., Oxford, Ohio 45056, USA]

\section{INTRODUCTION}

The golden mouse, Ochrotomys nuttalli ( $\mathrm{H}$ a r la n), a docile semiarboreal species, is one of the least studied small mammals in North America. Though the range of this species is fairly extensive (W a 11 a c e, 1968), limited population size attributed to unique habitat requirements probably accounts for a lack of knowledge regarding the functional aspects of this species. Although various components of its life history (Barbour, 1942; Goodpaster \& Hoffmeister, 1954; Andrews, 1963; P a ckard \& Garner, 1964), population dynamics (B l u s, 1966; W a ll a c e, 1968), behavior (D u n a w a y, 1955; M c Carley, 1958; E a s terla, 1968), and ecology (M c Carley, 1958) have been studied, no studies have been concerned with the bioenergetics of the golden mouse. In contrast, much research has been conducted on the bioenergetics of various small mammal species in an attempt to better understand their trophic relationships and population function (G oll e y, 1960; S h a r p, 1967; B a r r e t t, 1969; and others). 
The purpose of this study was to measure and evaluate various energetic parameters of golden mice maintained on three different laboratory diets to understand better their feeding strategy.

\section{METHODS}

Six adult males and two adult females were captured by hand from nests near Bighill, Madison County, Kentucky, U.S.A., in early December, 1973. The ratio of captured females to males was lower than reported in previous studies (Goodpaster \& $\mathrm{H}$ of $\mathrm{fme}$ is ter, 1954; W a lla ce, 1968). Interestingly, six of these animals (four males and two females) were caught in one large nest in a red cedar tree (Juniperus). Goodpaster \& Hoffmeister (1954) have reported finding nests with as many as five individuals in them. Captive animals were housed at the Ecology Research Center located on the Bachelor Wildlife Estate near Miami University, Oxford, Ohio. The mice were caged separately for seven weeks and fed Purina laboratory chow and a mixture of wild bird seed.

The food consumption method was used in this study since Odum, Connell \& Davenport (1962) proposed that this method was more accurate than the oxygen consumption method for energetic studies. Weight changes, food intake, and assimilation efficiencies, based on three diets, were measured for three separate 10-day periods (6 to 16 February, 4 to $14 \mathrm{March}$, and 1 to 11 April, 1974). Three males and one female were selected for these studies due to their similarity in weight. After completion of each diet, animals were returned to preexperimental housing and food conditions (i.e., caged separately and fed laboratory chow and wild bird seed) for at least one week. This period was followed by a one-week acclimation to the new diet. Feeding experiments were conducted in metabolic cages (B arrett, 1969) where food intake, feces, and urine were measured separately. The metabolic cages were contained in an environmental chamber maintained at $21^{\circ} \mathrm{C} \pm 1$ and a 12-hour photoperiod for all diets. Water was provided ad libitum.

The three experimental diets consisted of blended amounts of husked sunflower seeds (Helianthus annuus L.) and Purina laboratory chow in ratios (by weight) of $75 \%$ chow $-25 \%$ seed, $50 \%$ chow $-50 \%$ seed, $25 \%$ chow $-75 \%$ seed, diets $A, B$, and $C$, respectively. Each animal was weighed, and feces, urine, and uneaten food were collected daily. Feces and urine were oven-dried at $40^{\circ} \mathrm{C}$ for 72 hours and for one week, respectively, weighed, and stored for caloric analyses. All samples were thoroughly ground and homogenized with a Wiley mill. Ash-free caloric values of feces, urine, lab chow, and sunflower seeds were determined by Parr adiabatic bomb calorimetry. Computations for individual animals were based on pooled 10-day samples for feces and urine collected from each diet. Triplicate caloric determinations of the pooled materials produced mean values for each 10 -day period. Sunflower seeds and laboratory chow were dried, ground, and bombed, separately. Caloric content of each diet was calculated by proportion using these values. Mouse caloric content was assumed to be $2.14 \mathrm{kcal} / \mathrm{g}$ wet body weight as determined by Brisbin (1970). Values are expressed as $\mathrm{kcal} / \mathrm{g}$ wet body weight/day. Mean feces, urine, and experimental food (diet) caloric equivalents are shown in Table 1. 


\section{RESULTS AND DISCUSSION}

Mean energy flow diagrams for the four golden mice on the three experimental diets are shown in Figure 1. Energy flow for each diet was considered in the following manner: $I=A+N A, A=P+R+U$; where $I$ is ingested energy, $A$ is assimilated energy, $N A$ is nonassimilated energy (feces), $P$ is production, $R$ is respiration, and $U$ is urine. Assimilation and respiration were calculated by difference. As defined for this study, assimilation efficiency is the ratio of the energy actually assimilated divided by the energy ingested $\times 100$ ( $\mathrm{O} \mathrm{d} \mathrm{u} \mathrm{m}, 1971)$.

The mean group weights (g) were $20.62 \pm 2.09 \mathrm{SD}, 21.79 \pm 2.13 \mathrm{SD}$, and $23.40 \pm 2.89 \mathrm{SD}$, respectively, for the three diets. Table 2 summarizes analyses of variance using a split-plot in time with whole plots (mice) in a randomized complete block design to evaluate the effect of diet and day on the changes in body weight, ingestion, fecal production, urine production, assimilation, and assimilation efficiency. As noted, these

Table 1

Summary of caloric values used in this study. All values expressed as $\mathrm{kcal} / \mathrm{g}$ ash-free dry weight $\pm \mathrm{SD}$.

\begin{tabular}{cccc}
\hline Diet 1 & Experimental Food & Feces & Urine \\
\hline$A(75 \%$ chow $-25 \%$ seed $)$ & $4.94^{2}$ & $4.45 \pm 0.09$ & $2.87 \pm 0.04$ \\
$B(50 \%$ chow $-50 \%$ seed $)$ & 5.65 & $4.44 \pm 0.10$ & $3.01 \pm 0.09$ \\
$C(25 \%$ chow-75\% seed $)$ & 6.35 & $4.42 \pm 0.12$ & $2.91 \pm 0.08$ \\
\hline
\end{tabular}

1 Computations based on single determinations.

2 Caloric content of experimental diets based on caloric values for Purina laboratory chow and sunflower seeds of 4.23 and $7.06 \mathrm{kcal} / \mathrm{g}$ ash-free dry weight, respectively.

analyses indicated no significant weight changes due to the effect of diet or day. Owing to the fact that all experimental animals were of adult size (W a ll a c e, 1968) and, as a group, showed no significant weight change for any diet, it was assumed that no significant amount of energy was channeled into growth (production).

While use of the Duncan New Multiple Range Test (DNMRT) (D u n c a $n, 1955$ ) showed that the ingestion (g/g wet wt) rate for $\operatorname{diet} A$ was significantly greater $(P \leq .05)$ than $\operatorname{diet} C$, and that the ingestion rate for diet $B$ overlapped both of the other diets, no dietary effect was found for ingestion rates based on caloric content. Fecal production (g/g wet wt and $\mathrm{kcal} / \mathrm{g}$ wet $\mathrm{wt})$ on all diets differed significantly $(P \leq .05)$. Urine production (g/g wet wt and $\mathrm{kcal} / \mathrm{g}$ wet wt) values on $\operatorname{diets} A$ and $C$ differed significantly, whereas urine production for $\operatorname{diet} B$ was also found to overlap diets $A$ and $C$ (see Fig. 1 and Table 2). 
Mean assimilation efficiencies of all diets, $80.0 \%, 86.7 \%$, and $91.9 \%$, respectively, were significantly different (DNMRT; $P \leq .05)$ from each other. The high assimilation efficiency of the third diet $(C)$ is similar to that found for Oryzomys palustris (Harlan) feeding on animal material (S harp, 1967), Microtus pennsylvanicus (Ord) and Sigmodon hispidus

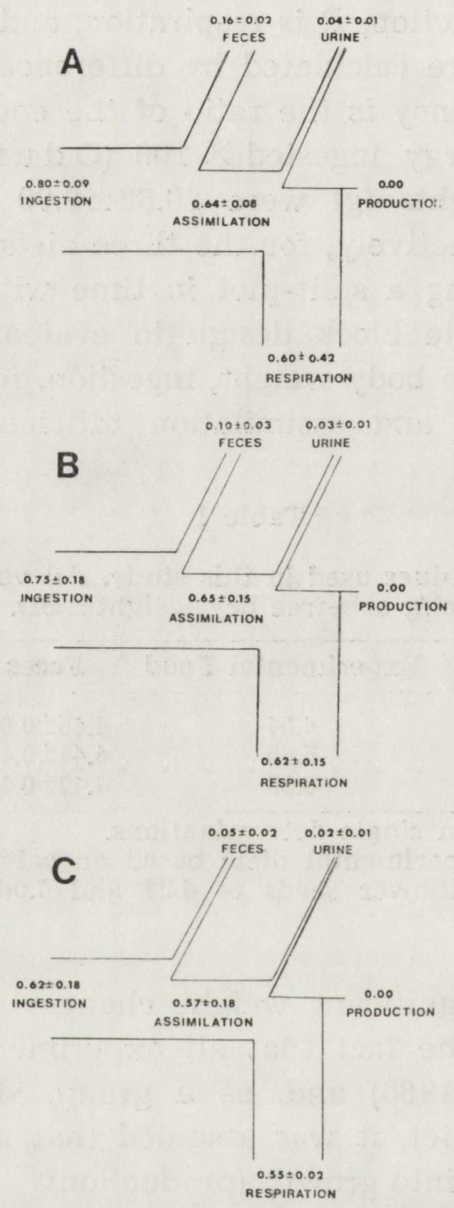

Fig. 1. Energy flow diagrams for the golden mouse on the three experimental diets: (A) $75 \%$ chow-25\% seeds; $(B) 50 \%$ chow $-50 \%$ seeds; and $(C)$ ) $25 \%$ chow $-75 \%$ seeds. All values expressed in $\mathrm{kcal} / \mathrm{g}$ body $\mathrm{wt} /$ day $\pm \mathrm{SD}$.

(Say \& Ord) feeding on green plant material (G o ll e y, 1959, 1960), and Peromyscus polionotus (Wagner) feeding on seeds (Connell, 1959).

In summary, our findings indicate that caloric needs of golden mice may be met by varying rates of food intake as a function of caloric composition. Golden mice also vary in their ability to assimilate diets 
which vary in dietary composition. D ro żd $\dot{z}$ (1968) also found that several herbivorous small mammals varied (from 65 to $95^{\%} \%$ ) in their ability to assimilate consumed energy depending on diet.

The ability of the golden mouse to adjust ingestion rates for food materials differing in caloric content is, no doubt, an adaptive advantage in view of the species' unique behavioral characteristcs. Grouping of mice in one nest, especially in winter, suggests the need for an efficient means of food collection, as well as a high assimilation efficiency. With

\section{Table 2}

Analysis of variance of the effect of diet and day on the changes in energetic parameters. All values expressed on a per $\mathrm{g}$ wet weight basis.

\begin{tabular}{|c|c|c|c|}
\hline \multirow{2}{*}{ Variables } & \multicolumn{3}{|c|}{ Sources of variations } \\
\hline & Diet & Day & Diet-day interaction \\
\hline Body weight (g) & $\begin{array}{l}7.64 \times 10^{1 \mathrm{a}} \\
4.76^{\mathrm{b}}\end{array}$ & $\begin{array}{l}2.22 \times 10^{-1} \\
0.25\end{array}$ & $\begin{array}{l}2.97 \times 10^{-1} \\
0.33\end{array}$ \\
\hline Ingestion (g) & $\begin{array}{l}4.06 \times 10^{-2} \\
14.16^{* *}\end{array}$ & $\begin{array}{l}7.71 \times 10^{-4} \\
1.77\end{array}$ & $\begin{array}{l}2.68 \times 10^{-4} \\
0.62\end{array}$ \\
\hline Ingestion (kcal) & $\begin{array}{l}3.30 \times 10^{-1} \\
3.61\end{array}$ & $\begin{array}{l}2.29 \times 10^{-2} \\
1.54\end{array}$ & $\begin{array}{l}8.67 \times 10^{-3} \\
0.58\end{array}$ \\
\hline Feces (g) & $\begin{array}{l}5.68 \times 10^{-3} \\
57.65^{* *}\end{array}$ & $\begin{array}{l}3.01 \times 10^{-5} \\
2.17^{*}\end{array}$ & $\begin{array}{l}1.35 \times 10^{-5} \\
0.97\end{array}$ \\
\hline Feces (kcal) & $\begin{array}{l}1.13 \times 10^{-1} \\
48.86^{* *}\end{array}$ & $\begin{array}{l}5.91 \times 10^{-4} \\
2.16^{*}\end{array}$ & $\begin{array}{l}2.59 \times 10^{-4} \\
0.97\end{array}$ \\
\hline Urine $(\mathrm{g})$ & $\begin{array}{l}2.43 \times 10^{-4} \\
7.60^{*}\end{array}$ & $\begin{array}{l}1.91 \times 10^{-6} \\
0.38\end{array}$ & $\begin{array}{l}5.43 \times 10^{-6} \\
1.09\end{array}$ \\
\hline Urine (kcal) & $\begin{array}{l}1.77 \times 10^{-3} \\
6.45^{*} \\
\end{array}$ & $\begin{array}{l}1.65 \times 10^{-5} \\
0.39\end{array}$ & $\begin{array}{l}4.72 \times 10^{-5} \\
1.11\end{array}$ \\
\hline Assimilation (kcal) & $\begin{array}{l}8.61 \times 10^{-2} \\
1.31\end{array}$ & $\begin{array}{l}1.71 \times 10^{-2} \\
1.35\end{array}$ & $\begin{array}{l}6.98 \times 10^{-3} \\
0.56\end{array}$ \\
\hline $\begin{array}{l}\text { Assimilation } \\
\text { efficiency }(\%)\end{array}$ & $\begin{array}{l}1.37 \times 10 \\
515.65^{* *}\end{array}$ & $\begin{array}{l}2.78 \\
0.78\end{array}$ & $\begin{array}{l}2.98 \\
0.84\end{array}$ \\
\hline
\end{tabular}

a Mean square, b $\mathrm{F}$ value. * Significant at $P \leq .05$. ** Significant at $P \leq .01$.

a relatively high population density, often within a specific habitat site, the golden mouse may thus be able (a) to select foods high in caloric content, and (b) to assimilate efficiently various food types. Furthermore, early breeding, which normally occurs from March to October ( $G$ o o d paster \& Hoffmeister, 1954), may necessitate more territorial behavior in order to acquire energy needs. This hypothesis was substantiated by a second trip to the initial collection site in early May, 1974. Three adult females were captured, each in a separate nest. This suggests that breeding may lead to territorial behavior based on caloric 
needs. Further studies of this species should focus upon its bioenergetics and behavior in its natural habitat.

Acknowledgments: We wish to thank Dr. Roger W. Barbour, University of Kentucky, for his advice in helping to locate collecting sites. We are also grateful to Janet Ford, Jill A uburn, Jenny Burris, and Susan Snow for field assistance. Special thanks are also extended to Drs. Guy C. C a m e r o n, University of Houston, and Frank B. Golley and Richard G. W i e gert, University of Georgia, for their comments and constructive criticism of the manuscript.

\section{REFERENCES}

1. Andrews R. D., 1963: The golden mouse in Southern Illinois. Chicago Acad. Sci., Nat Hist. Misc. no. 179.

2. Barbour R. W., 1942: Nests and habitat of the golden mouse in eastern Kentucky. J. Mammal., 23: 90-91.

3. B a r r e t t G. W., 1969: Bioenergetics of a captive least shrew, Cryptotis parva. J. Mammal., 50: 629-630.

4. Blus L. J., 1966: Relationship between litter size and latitude of the golden mouse. J. Mammal., 47: 546-547.

5. Brisbin L. L., 1970: A determination of live-weight caloric conversion factors for laboratory mice. Ecology, 51: $541-544$.

6. Connel1 C. E., 1959: Seasonal lipid levels in three populations groups of an old-field ecosystem. Ph. D. dissertation, Univ. Georgia, Athens, $107 \mathrm{pp}$.

7. D r o żdż A., 1968: Digestibility and assimilation of natural foods in small rodents. Acta theriol., 13: $367-389$.

8. Dunaway P. B., 1955: Late fall home ranges of three golden mice, Peromyscus nuttalli. J. Mammal., 36: 297-298.

9. Duncan D. B., 1955: Multiple range and multiple F-tests. Biometrics, 11: $1-42$.

10. Easterla D. A., 1968: Terrestrial home site of golden mice. Amer. Midl. Nat., 79: 246-247.

11. Golle y F. B., 1959: Energy flow through the cotton rat, Sigmodon hispidus. The ASB Bull., 6: 24.

12. Golley F. B., 1960: Energy dynamics of a food chain of an old-field community. Ecol. Monogr., 30: 186-206.

13. Goodpaster W. W. \& Hoffmeister D. F., 1954: Life history of the golden mouse, Peromyscus nuttalli, in Kentucky. J. Mammal., 35: 16-27.

14. M c Carley W. H., 1958: Ecology, behavior and population dynamics of Peromyscus nuttalli in eastern Texas. Texas J. Sci., 10: 147-171.

15. O d u m E. P., 1971: Fundamentals of ecology. W. B. Saunders Company: 1-574. Philadelphia.

16. Odum E. P., Connell C. E. \& Davenport L. B., 1962: Population energy flow of three primary consumer components of old-field ecosystems. Ecology, 43: $88-96$.

17. P a ckard R. L. \& G a rn er H., 1964: Arboreal nests of the golden mouse in Eastern Texas. J. Mammal., 45: 369-374.

18. Sharp H. F., Jr., 1967: Food ecology of the rice rat, Oryzomys palustris (Harlan), in a Georgia salt marsh. J. Mammal., 48: 557-563.

19. W a 11 a c e J. T., 1968: Some notes on the growth, development and distribution of Ochrotomys nuttalli (Harlan) in Kentucky. Trans. Kent. Acad. Sci., 29: $45-52$. 
Karen L. STUECK, Michael P. FARRELL i Gary W. BARRETT

ENERGETYKA EKOLOGICZNA OCHROTOMYS NUTTALLI

Streszczenie

Oszacowano zmienność parametrów energetycznych Ochrotomys nuttalli (H a rla n) dla trzech różnych diet laboratoryjnych (Tabela 1). Nie znaleziono statystycznie istotnych zmian $\mathrm{w}$ ciężarze między grupami, które mogłyby wynikać z wpływu diety. Wystąpily istotne różnice $(P \leq 0.05)$ w pobraniu pokarmu między najwyższą i najniższą kalorycznie dietą, nie stwierdzono natomiast różnic w pobraniu energii w kaloriach. Produkcja kału przy wszystkich dietach istotnie różniła się od siebie $(P \leq 0.05)$. Zgodnie $\mathrm{z}$ tym, średni poziom asymilacji przy karmieniu tymi dietami był też istotnie różny $(P \leq 0.05$; Tabela 2$)$. Wyniki wskazują, że zapotrzebowanie kaloryczne tego gatunku gryzonia ujawnia się poprzez różny poziom pobrania pokarmu, jako funkcja składu (kaloryczności) diety (Ryc. 1). 